\title{
Stability Indicating Simultaneous Validation of Telmisartan and Cilnidipine with Forced Degradation Behavior Study by RP-HPLC in Tablet Dosage Form
}

\author{
Reema H. Rupareliya and Hitendra S. Joshi \\ Department of Chemistry, Saurashtra University, Rajkot, Gujarat-360 005, India \\ Correspondence should be addressed to Hitendra S. Joshi; drhsjoshi49@gmail.com
}

Received 26 October 2013; Accepted 25 November 2013

Academic Editors: B. K. Mandal and M. L. Trehy

Copyright (C) 2013 R. H. Rupareliya and H. S. Joshi. This is an open access article distributed under the Creative Commons Attribution License, which permits unrestricted use, distribution, and reproduction in any medium, provided the original work is properly cited.

\begin{abstract}
A simple, precise, and accurate RP-HPLC method has been developed and validated for the simultaneous assay of Telmisartan and Cilnidipine in tablets. Isocratic RP-HPLC method was developed on Waters C18 $250 \times 4.6 \mathrm{~mm}, 5 \mu \mathrm{m}$ column using mobile phase as acetonitrile $(\mathrm{ACN})$ : buffer $\mathrm{pH} 3.0$ with orthophosphoric acid $(68: 32)$ at a flow rate of $1.0 \mathrm{~mL} / \mathrm{min}$ and the detection was carried out at $245 \mathrm{~nm}$ using photodiode array detector. Forced degradation study was carried out by oxidation, hydrolysis, photolysis, and heating the drug. The method was validated for specificity, linearity, precision, accuracy, robustness, and solution stability. The method was found to be linear in the concentration range of $40-160 \mu \mathrm{g} / \mathrm{mL}$ with correlation coefficient of 0.9990 for Telmisartan and $10-40 \mu \mathrm{g} / \mathrm{mL}$ with correlation coefficient of 0.9989 for Cilnidipine. Degradation products produced as a result of stress studies did not interfere with the detection of agomelatine; therefore, the assay can be considered to be stability indicating.
\end{abstract}

\section{Introduction}

Telmisartan is chemically nominated as $4^{\prime}$-[(1,4'-dimethyl$2^{\prime}$-propyl[2,6'-bi-1H-benzimidazole $]-1^{\prime}$-yl) methyl] $\left[1,1^{\prime}\right.$ biphenyl]-2-carboxylic acid (Figure 1). Its molecular formula is $\mathrm{C}_{33} \mathrm{H}_{30} \mathrm{~N}_{4} \mathrm{O}_{2}$ and molecular weight is 514.62. It is a diabetes angiotensin receptor blocker that shows high affinity for the angiotensin II type 1 (AT1) receptors, has a long duration of action, and has the longest half-life of any angiotensin II receptor blocker (ARB) [1]. In clinical studies, Telmisartan shows comparable antihypertensive activity to other major antihypertensive classes, such as angiotensin converting enzyme (ACE) inhibitors, beta-blockers, and calcium antagonists [2].

Cilnidipine is chemically nominated as 1,4-dihydro-2,6dimethyl-4-(3-nitrophenyl)-3,5-pyridine carboxylic acid 2methoxyethyl(2E)-3-phenyl-propenyl ester (Figure 2). It is a dual blocker of L-type voltage-gated calcium channels in vascular smooth muscle and N-type calcium channels in sympathetic nerve terminals that supply blood vessels [3].

The parent drug stability test guideline Q1A (R2) issued by the International Conference on Harmonization (ICH) suggests that stress testing is an essential part of development strategy and is carried out under more serve condition than accelerated conditions. These studies provide information to establish its inherent stability characteristics, leading to identification of degradation products and hence supporting the suitability of the proposed analytical methods. [4-6]. According to ICH guidelines stress testing should include the effect of temperature, light, oxidizing agents and susceptibility across a wide range of $\mathrm{pH}$ values and separation of drugs from degradation products [7]. It is also suggested that analysis of stability sample should be done by using validated stability testing methods.

There are many reported methods for analysis of Telmisartan [8-13] and Cilnidipine [3, 14-16] either alone or in combination with other drugs in pharmaceutical dosage forms or individually in biological fluids. Simultaneous RPHPLC and HPTLC estimation of Telmisartan and Cilnidipine in combined tablet dosage form has been reported $[17,18]$. To our knowledge there has been no stability indicating RP-HPLC method reported for Telmisartan and Cilnidipine combination in which $\mathrm{ICH}$ recommended that stress 


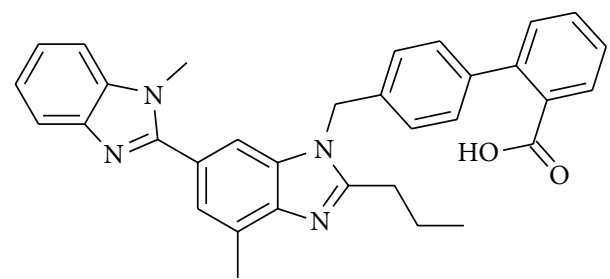

Figure 1: Chemical structure of Telmisartan.

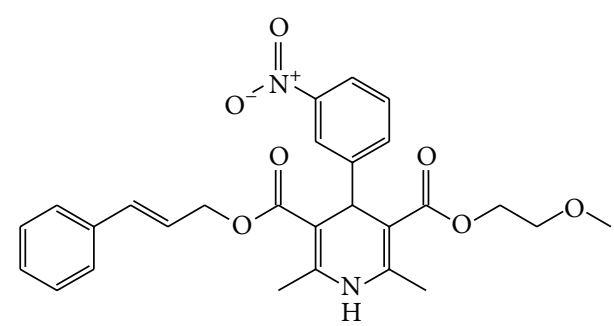

O3-(2-Methoxyethyl) O5-[(E)-3-phenylprop-2-enyl] 2,6-dimethyl-4-(3-nitrophenyl)-1,4-dihydropyridine-3,5dicarboxylate

Figure 2: Chemical structure of Cilnidipine.

conditions be applied. Therefore, the stability indicating method was developed by applying different stress conditions like acidic, alkali, $\mathrm{H}_{2} \mathrm{O}_{2}$, thermal, and photodegradation.

\section{Experimental}

2.1. Instrumentation. The chromatographic system used to perform development and validation of this assay method was comprised of a LC-10AT $v p$ binary pump, a SPD-M10Avp photodiode array detector, and a Rheodyne manual injector model $7725 \mathrm{i}$ with $20 \mu \mathrm{L}$ loop (Shimadzu, Kyoto, Japan) connected to a multi-instrument data acquisition and data processing system (LC solution, Shimadzu).

2.2. Reagents and Reference Substance. Telmisartan and Cilnidipine standards were provided by Unique Chemicals, Panoli, India, and CPL Chemicals, Ankleshvar, India, respectively. Cilacar T tablets containing $40 \mathrm{mg}$ Telmisartan and $10 \mathrm{mg}$ Cilnidipine were obtained from market. HPLC grade ACN was obtained from Spectrochem Pvt. Ltd., Mumbai, India. HPLC grade water was produced in-house by using Milli Q (Millipore, Milford, USA) system. Membrane filters of $0.45 \mu \mathrm{m}$ (Millipore) were used. Analytical grade sodium phosphate monobasic dihydrate was obtained from Sisco Research Laboratories, Mumbai, India. Hydrochloric acid, glacial acetic acid, sodium hydroxide pellets, and 30\% v/v hydrogen peroxide solution were obtained from Ranbaxy Fine Chemicals, New Delhi, India.

2.3. Chromatographic Conditions. Chromatographic analysis was performed on Waters C $18(250 \mathrm{~mm} \times 4.6 \mathrm{~mm}$ i.d., $5 \mu \mathrm{m}$ particle size) column at ambient temperature. The mobile phase consisted of $\mathrm{ACN}$ : $0.01 \mathrm{M}$ sodium phosphates monobasic dehydrate buffer $\mathrm{pH} 3.0$ with phosphoric acid $(68: 32, \mathrm{v} / \mathrm{v})$. Buffer solution was filtered through a $0.45 \mu \mathrm{m}$ nylon membrane (Millipore Pvt. Ltd. Bangalore, India) and mobile phase was degassed in an ultrasonic bath (Spincotech Pvt. Ltd., Mumbai). The flow rate of the mobile phase was adjusted to $1.0 \mathrm{~mL} / \mathrm{min}$ and the injection volume was $20 \mu \mathrm{L}$. Detection was performed at $245 \mathrm{~nm}$.

2.4. Standard Preparation. Standard solution containing Telmisartan $(100 \mu \mathrm{g} / \mathrm{mL})$ and Cilnidipine $(25 \mu \mathrm{g} / \mathrm{mL})$ was prepared by dissolving accurately about $100.0 \mathrm{mg}$ Telmisartan and $25.0 \mathrm{mg}$ Cilnidipine in $100 \mathrm{~mL}$ volumetric flask by diluent (methanol) (stock standard solution). $10 \mathrm{~mL}$ of stock solution was pipetted out into $100 \mathrm{~mL}$ volumetric flask and diluted up to mark with diluent to get concentration $100 \mu \mathrm{g} / \mathrm{mL}$ for Telmisartan and $25 \mu \mathrm{g} / \mathrm{mL}$ for Cilnidipine.

2.5. Test Preparation. Twenty tablets were weighed and the average weight of tablet was determined. From these, five tablets were weighed and transferred into a $500 \mathrm{~mL}$ volumetric flask. About $50 \mathrm{~mL}$ diluent was added and sonicated for a minimum of $30 \mathrm{~min}$. with intermittent shaking.

Then content was brought back to room temperature and diluted to volume with diluent. The sample was filtered through $0.45 \mu \mathrm{m}$ nylon syringe filter. $25 \mathrm{~mL}$ of filtrate stock solution was pipetted out into $100 \mathrm{~mL}$ volumetric flask and diluted up to mark with diluent. The concentration obtained was $100 \mu \mathrm{g} / \mathrm{mL}$ of Telmisartan and $25 \mu \mathrm{g} / \mathrm{mL}$ of Cilnidipine.

2.6. Degradation Study. The degradation samples were prepared by transferring powdered tablets, which had been equivalent to $40.0 \mathrm{mg}$ Telmisartan and $10.0 \mathrm{mg}$ Cilnidipine, into a $250 \mathrm{~mL}$ round bottomed flask. Then drug content was employed for acidic, alkaline, and oxidant media and also for thermal and photolytic stress conditions. After the degradation treatments were completed, the stress content solutions were allowed to equilibrate to room temperature and diluted with diluent to attain $100 \mu \mathrm{g} / \mathrm{mL}$ Telmisartan and $25 \mu \mathrm{g} / \mathrm{mL}$ Cilnidipine concentration. Specific degradation conditions were described as follows.

2.7. Acidic Degradation Condition. Acidic degradation study was performed by heating the drug content in $1 \mathrm{~N} \mathrm{HCl}$ at $60^{\circ} \mathrm{C}$ for $30 \mathrm{~min}$ and mixture was neutralized.

2.8. Alkali Degradation Condition. Alkaline degradation study was performed by ambient temperature in $1 \mathrm{~N} \mathrm{NaOH}$ for $30 \mathrm{~min}$ and mixture was neutralized.

2.9. Oxidative Degradation Condition. Oxidation degradation study was performed by heating the drug content in $30 \%$ v/ $/ \mathrm{H}_{2} \mathrm{O}_{2}$ at $80^{\circ} \mathrm{C}$ for 1 hour. Here $80^{\circ} \mathrm{C}$ temperature was used because at $60^{\circ} \mathrm{C}$ degradation was not obtained.

2.10. Thermal Degradation Condition. Thermal degradation was performed by exposing solid drug to dry heat of $80^{\circ} \mathrm{C}$ 
in a conventional oven for $72 \mathrm{hr}$. Here $80^{\circ} \mathrm{C}$ temperature was used because at $60^{\circ} \mathrm{C}$ degradation was not obtained.

2.11. Photolytic Degradation Condition. Photolytic degradation study was performed by exposing the drug content in UV-light for $72 \mathrm{hr}$.

\section{Method Validation}

3.1. Specificity Study. The specificity of the method was determined by checking the interference of placebo with analyte and the proposed method was eluted by checking the peak purity of Telmisartan and Cilnidipine during the force degradation study. The peak purity of the Telmisartan and Cilnidipine was found to be satisfactory (0.9999) and (0.9998) under different stress conditions. There was no interference of any peak of degradation product with drug peak.

3.2. Linearity. Linearity test solutions for the assay method were prepared at seven concentration levels from 40 to $160 \%$ of assay analyte concentration $(40,60,80,100,120,140$, and $160 \mu \mathrm{g} / \mathrm{mL}$ ) with correlation coefficient of 0.9990 for telmisartan and $(10,15,20,25,30,35$, and $40 \mu \mathrm{g} / \mathrm{mL})$ with correlation coefficient of 0.9989 for Cilnidipine. The peak areas versus concentration data were evaluated by linear regression analysis.

3.3. $L O D$ and LOQ. The limit of detection and limit of quantification were evaluated by serial dilutions of telmisartan and Cilnidipine stock solution in order to obtain signal-to-noise ratio of $3: 1$ for LOD and 10:1 for LOQ.

3.4. Precision. The precision of the assay method was evaluated in terms of repeatability by carrying out six independent assays of telmisartan and Cilnidipine test sample preparation and calculated the \% RSD of assay (intraday). Intermediate precision of the method was checked by performing same procedure on a different day (interday) by another person under experimental condition.

3.5. Accuracy. An accuracy study was performed by adding known amounts of Telmisartan and Cilnidipine to the placebo preparation. The actual and measured concentrations were compared. Recovery of the method was evaluated at three different concentration levels (corresponding to 50, 100 , and $150 \%$ of test preparation concentration). For each concentration level, three sets were prepared and injected in duplicate.

3.6. Robustness. The robustness of study was carried out to evaluate the influence of small but deliberate variations on the chromatographic conditions. The factors chosen for this study were the flow rate $( \pm 0.1 \mathrm{~mL} / \mathrm{min})$, mobile phase composition [ACN-buffer $(70: 30$ and $66: 34, \mathrm{v} / \mathrm{v})]$, and using different lot of LC column.

3.7. Solution Stability. The stability study of solution for test preparation was carried out. The solution was stored at

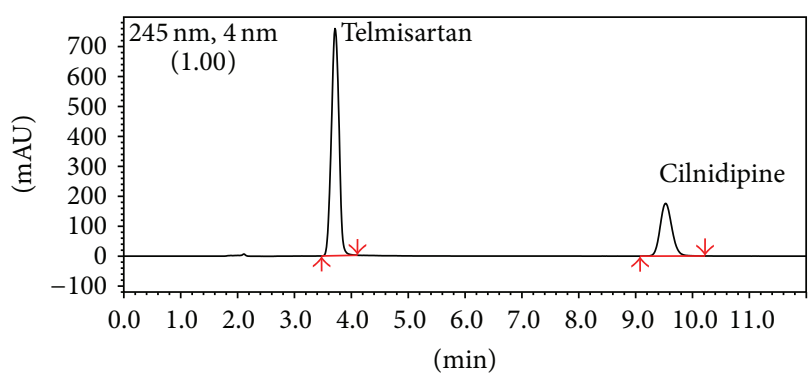

FIGURE 3: Chromatogram of standard preparation.

ambient temperature $2-5^{\circ} \mathrm{C}$ and tested at intervals of 12 , 24,36 , and $48 \mathrm{hr}$. The responses for the aged solution were evaluated using a freshly prepared standard solution.

3.8. Result and Discussion. An analytical method based on LC with UV detection was developed and validated for assay and determination of Telmisartan and Cilnidipine in tablet dosage forms. The analytical conditions were selected after testing the different parameters such as diluents, buffer, buffer concentration, organic solvent for mobile phase and mobile phase composition, and other chromatographic conditions. Our preliminary trials using different compositions of mobile phases, consisting of water with methanol or acetonitrile, did not give good peak shape. Then different $\mathrm{pH}$ of water was used with methanol and acetonitrile, but good peak shape was not obtained. By keeping mobile phase composition CAN-0.01 M sodium phosphate monobasic dehydrate buffer $(68: 32, \mathrm{v} / \mathrm{v}) \mathrm{pH} 3$, best peak shape was obtained. For the selection of organic constituent of mobile phase, acetonitrile was chosen to reduce the longer retention time and to attain good peak shape. A detection wavelength of $245 \mathrm{~nm}$ was selected after scanning the standard solution over the range $190-370 \mathrm{~nm}$ by use of the PDA detector. Detection at $245 \mathrm{~nm}$ resulted in good response and good linearity. Chromatogram of standard preparation is represented in Figure 3.

The drug substance was easily extracted from the pharmaceutical dosage form using methanol. The tablet dispersed readily in water and the drug substance was freely soluble in methanol. Solutions of standard and test preparation were found to be stable in methanol which was used as a diluent.

After development of the analytical method, it was validated in accordance with ICH and USP guidelines. This furnished evidence that the method was suitable for its intended purpose. The intensive approach described in this paper was used to develop and validate a liquid chromatographic analytical method that can be used for assay validation of telmisartan and Cilnidipine in a pharmaceutical dosage form. Degradation product produced as a result of stress did not interfere with detection of Telmisartan and Cilnidipine and the assay method can thus be regarded as stability indicating.

The specificity of the method was evaluated by checking the interference of placebo with analyte and the proposed method was evaluated by checking the peak purity of Telmisartan and Cilnidipine during the force degradation study. There was no interference of any peak of degradation product with drug peak. 


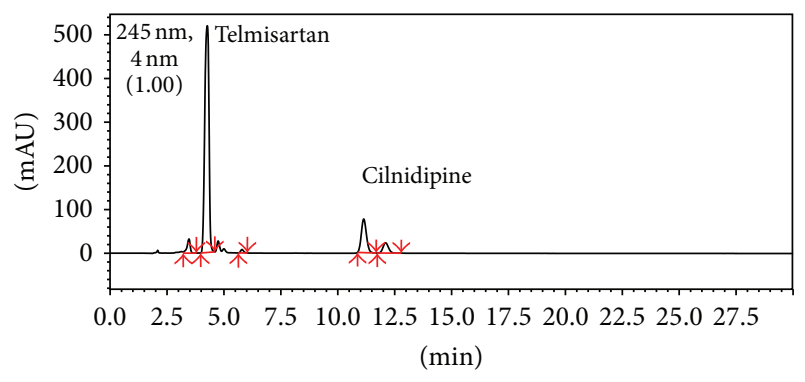

FIGURE 4: Chromatogram of alkali forced degradation study.

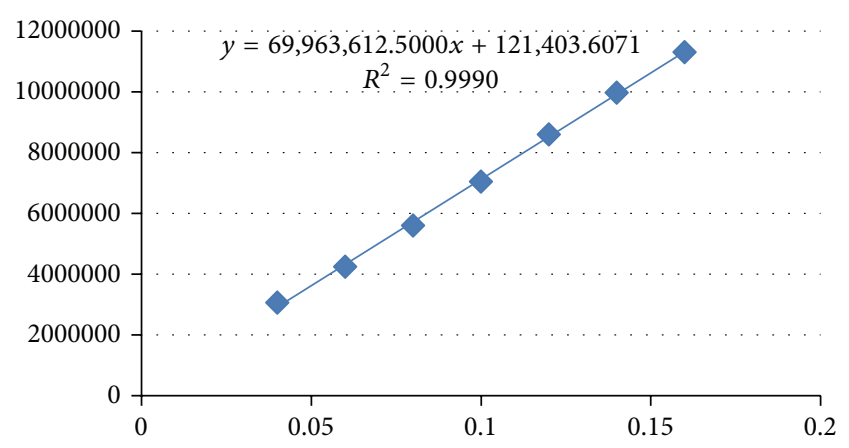

FIGURE 5: Linearity curve for Telmisartan.

Major degradation was found in alkali condition that product was degraded up to $5.74 \%$ for Telmisartan where two degradation peaks were found at 3.460 and 5.786, while for Cilnidipine the product was degraded up to $32.99 \%$ at $12.096 \mathrm{~min}$. (Figure 4). There was no degradation found in acid, $3 \% \mathrm{H}_{2} \mathrm{O}_{2}, 30 \% \mathrm{H}_{2} \mathrm{O}_{2}$, thermal and photo degradation for both Telmisartan and Cilnidipine.

To determine linearity a calibration graph was obtained by plotting Telmisartan and Cilnidipine concentration (mg/ $\mathrm{mL}$ ) against peak area. Linearity was good in the concentration range $40-160 \mu \mathrm{g} / \mathrm{mL}$ for Telmisartan (Figure 5) and $10-40 \mu \mathrm{g} / \mathrm{mL}$ for Cilnidipine (Figure 6). The response of the drug was found to be linear. The regression equation for Telmisartan was $y=69,963,612.50 x+121,403.61$ with correlation coefficient 0.9990 and for Cilnidipine was $y=$ $100,294,307.14+21,397.04$ with correlation coefficient 0.9989 where $x$ is the concentration in $\mu \mathrm{g} / \mathrm{mL}$ and $y$ is the peak area in absorbance units (AU).

The LOD values for telmisartan and Cilnidipine were found to be $0.01 \mathrm{ppm}$ and $0.09 \mathrm{ppm}$, respectively. The LOQ values for telmisartan and Cilnidipine were $0.06 \mathrm{ppm}$ and $0.4 \mathrm{ppm}$.

For assay of Telmisartan $(n=6)$, RSD of system precision was $0.20 \%$ on the same day (intraday) and $0.36 \%$ on different days (interday). The mean values of $\%$ assay and $\%$ RSD for method precision (repeatability) were $100.35 \%$ and $0.43 \%$, respectively, for assay on same day (intraday), while $99.72 \%$ and $0.56 \%$, respectively, for assay on different days (interday).

For assay of Cilnidipine $(n=6)$, RSD of system precision was $0.14 \%$ on the same day (intraday) and $0.22 \%$ on different days (interday). The mean values of \% assay and \% RSD

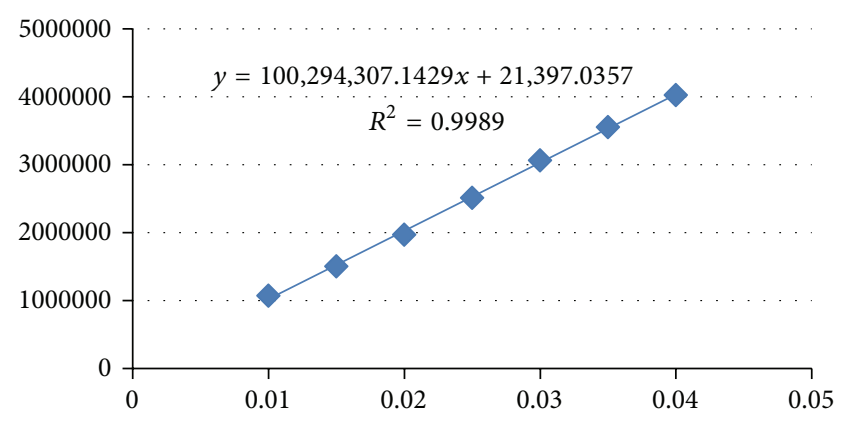

FIGURE 6: Linearity curve for Cilnidipine.

for method precision (repeatability) were $99.83 \%$ and $0.86 \%$, respectively, for assay on the same day (intraday), while $99.93 \%$ and $0.45 \%$, respectively, for assay on different days (interday).

Intermediate precision was established by determining the overall (intraday and interday) method precision. For intermediate precision $(n=12)$, overall \% assay and \% RSD value was $100.04 \%$ and $0.58 \%$, respectively, for Telmisartan, while $99.88 \%$ and $0.66 \%$ for Cilnidipine. The precise result for content uniformity was indicative of uniform distribution of the drug in the tablets without significant variation; this is in accordance with the USP, which stipulates acceptance limits for drug content uniformity and RSD as $85-115 \%$ and $<6 \%$, respectively [19].

The accuracy of the method was assessed by determination of recovery for three concentrations covering the range of the method. Known amounts $(50,100$, and $150 \mu \mathrm{g} / \mathrm{mL})$ for Telmisartan and $(12.5,25.0$, and $37.5 \mu \mathrm{g} / \mathrm{mL})$ for Cilnidipine were added to a placebo preparation and the amount of Telmisartan and Cilnidipine recovered, in the presence of placebo interface, was calculated. The mean recovery of Telmisartan was $98.37 \%$, 98.09\%, and 99.79\%, respectively, and the mean recovery of Cilnidipine was 99.68\%, 98.89\%, and $99.52 \%$, respectively (Table 1 ).

The robustness of the method was assessed by assaying test solutions under different analytical conditions deliberately changed from the original conditions. For each different analytical condition the standard solution and test solution were prepared separately. The result obtained from assay of the test solution was not affected by varying the conditions and was in accordance with the true value. System suitability data were also found to be satisfactory during variation of the analytical conditions (Table 2). The analytical method therefore remains unaffected by slight but deliberate changes in the analytical conditions.

During the study of the stability of stored solutions of standards and test preparations for assay determination the solutions were found to be stable for up to $48 \mathrm{hr}$. Assay values obtained after $48 \mathrm{hr}$ were statistically identical with the initial value without measurable loss (Table 3 ).

Before each measurement of validation data a system suitability test was performed by measurement of general characteristics such as peak asymmetry, number of theoretical plates, and RSD (\%) of peak area observed for 
TABLE 1: Evaluation data of accuracy study.

\begin{tabular}{cccccc}
\hline & Level (\%) & $\begin{array}{c}\text { Theoretical concentration } \\
(\mathrm{mg} / \mathrm{mL})\end{array}$ & $\begin{array}{c}\text { Observed concentration }^{\mathrm{a}} \\
(\mathrm{mg} / \mathrm{mL})\end{array}$ & \% Recovery $^{\text {\% RSD }}$ \\
\hline \multirow{3}{*}{ Telmisartan } & 50 & 0.04998 & 0.04917 & 98.37 & 1.68 \\
& 100 & 0.09995 & 0.09804 & 98.09 & 0.58 \\
& 150 & 0.14993 & 0.14963 & 99.79 & 1.20 \\
\hline \multirow{3}{*}{ Cilnidipine } & 50 & 0.01253 & 0.01246 & 99.69 & 0.49 \\
& 100 & 0.02505 & 0.02477 & 98.89 & 0.13 \\
& 150 & 0.03752 & 0.03734 & 99.52 & 0.15 \\
\hline
\end{tabular}

${ }^{\mathrm{a}}$ Each value corresponds to the mean of six determinations.

TABLE 2: Evaluation data of robustness study.

\begin{tabular}{lccc}
\hline \multirow{2}{*}{ Robust conditions } & \multirow{2}{*}{ \% Assay } & \multicolumn{2}{c}{ System suitability parameters } \\
& & Theoretical plates & Asymmetry \\
\hline Flow $0.9 \mathrm{~mL} / \mathrm{min}$. & 100.31 & 3448 & 1.03 \\
Flow $1.1 \mathrm{~mL} / \mathrm{min}$. & 99.76 & 3372 & 0.98 \\
Buffer-ACN & 99.77 & 3397 & 1.02 \\
$(34: 66, \mathrm{v} / \mathrm{v})$ & & 3362 & 1.07 \\
$\begin{array}{l}\text { Buffer-ACN } \\
(30: 70, \mathrm{v} / \mathrm{v})\end{array}$ & 99.76 & 3290 & 1.03 \\
Column change & 100.37 & & \\
\hline
\end{tabular}

TABLE 3: Evaluation data of stability study.

\begin{tabular}{lcccc}
\hline Intervals & $\begin{array}{c}\text { \% Assay for test solution } \\
\text { stored at } 2-8^{\circ} \mathrm{C}\end{array}$ & \multicolumn{2}{c}{$\begin{array}{c}\text { Assay for test solution } \\
\text { stored at ambient } \\
\text { temperature }\end{array}$} \\
& Telmisartan & Cilnidipine & Telmisartan & Cilnidipine \\
\hline Initial & 99.56 & 99.71 & 99.99 & 99.66 \\
$12 \mathrm{~h}$ & 99.61 & 99.85 & 100.11 & 100.17 \\
$24 \mathrm{~h}$ & 99.54 & 99.84 & 100.14 & 99.77 \\
$36 \mathrm{~h}$ & 99.98 & 99.23 & 100.18 & 99.45 \\
$48 \mathrm{~h}$ & 99.74 & 100.15 & 99.89 & 100.20 \\
\hline
\end{tabular}

a standard solution. The values obtained were satisfactory and in accordance with in-house limits (Tables 4 and 5).

\section{Conclusion}

This LC method for simultaneous assay validation of Telmisartan and Cilnidipine in a tablet formulation was successfully developed and validated for its intended purpose. In this study, stability of Telmisartan and Cilnidipine in present dosage form was established through employment of ICH recommended stress condition. The developed procedure has been evaluated over the specificity, linearity, accuracy, precision, and robustness in order to ascertain the stability of the analytical method. It has been proved that it was specific, linear, precise, accurate, robust, and stability indicating. Hence, the method is recommended for routine quality control analysis and also stability sample analysis.
TABLE 4: Evaluation data of system suitability study for Telmisartan.

\begin{tabular}{lccc}
\hline $\begin{array}{l}\text { System suitability data } \\
\text { In-house limit }\end{array}$ & $\mathrm{NMT}^{\mathrm{b}}$ 2.0 & $\begin{array}{c}\text { Theoretical } \\
\text { plates } \\
\text { NLT }^{\mathrm{c}} \text { 2000 }\end{array}$ & $\begin{array}{c}\text { Asymmetry } \\
\mathrm{NMT}^{\mathrm{b}} 2.0\end{array}$ \\
\hline Specificity & 1.02 & 3628 & 1.24 \\
Linearity & 0.53 & 3290 & 1.46 \\
Precision & 0.20 & 3799 & 1.34 \\
Intermediate & 0.36 & 3730 & 1.38 \\
precision & 0.83 & 3528 & 1.29 \\
Accuracy & 0.16 & 3026 & 1.20 \\
Solution stability & 0.71 & 3413 & 1.45 \\
Robustness &
\end{tabular}

${ }^{\mathrm{b}}$ Means not more than and ${ }^{\mathrm{c}}$ means not less than.

TABLE 5: Evaluation data of system suitability study for cilnidipine.

\begin{tabular}{lccc}
\hline $\begin{array}{l}\text { System suitability data } \\
\text { In-house limit }\end{array}$ & NMT $^{\mathrm{b}}$ 2.0 & $\begin{array}{c}\text { Theoretical } \\
\text { plates } \\
\text { NLT }^{\mathrm{c}} 2000\end{array}$ & $\begin{array}{c}\text { Asymmetry } \\
\mathrm{NMT}^{\mathrm{b}} 2.0\end{array}$ \\
\hline Specificity & 0.26 & 10214 & 1.35 \\
Linearity & 0.69 & 9823 & 1.23 \\
Precision & 0.14 & 10195 & 1.29 \\
Intermediate & 0.22 & 10166 & 1.40 \\
precision & 0.55 & 10081 & 1.38 \\
Accuracy & 0.29 & 10372 & 1.15 \\
Solution stability & 0.62 & 10224 & 1.26 \\
Robustness &
\end{tabular}

${ }^{\mathrm{b}}$ Means not more than and ${ }^{\mathrm{c}}$ means not less than.

\section{Acknowledgments}

The authors are thankful to Unique Chemicals, Panoli, India, and CPL Chemicals, Ankleshvar, India, for providing Telmisartan and Cilnidipine standard and facilities and Grants given under UGC-Special Assistance Programme Department Research Support (DRS) and Department of Science \& Technology (DST), New Delhi, Fund For Improvement of Science \& Technology (FIST), National Facility for Drug Discovery (NFDD), and Department of Chemistry, Saurashtra University, Rajkot-360 005, india, for providing analytical facilities. 


\section{References}

[1] M. Rama Mohana Reddy, A. Praveen Kumar, V. Krishna Reddy, and S. Wasimul Haque, "Stability-indicating hplc method for simultaneous estimation of low level impurities of telmisartan and hydrochlorothiazide in tablet dosage forms," International Journal of Pharmacy and Pharmaceutical Sciences, vol. 4, no. 1, pp. 497-504, 2012.

[2] A. Gupta, R. M. Charde, and M. S. Charde, "Determination of telmisartan and forced degradation behavior by RP-HPLC in tablet dosage form," International Journal of Pharmaceutical Chemistry, vol. 2, no. 3, pp. 93-99, 2012.

[3] M. S. Mohammed, "Spctrophotometric method for the estimation of cilnidipine in bulk and pharmaceutical dosage forms," Oriental Journal of Chemistry, vol. 29, no. 1, pp. 131-134, 2013.

[4] A. S. Rathore, L. Sathiyanarayanan, and K. R. Mahadik, "Stability-indicating high-performance thin-layer chromatographic method for quantitative estimation of emtricitabine in bulk drug and pharmaceutical dosage form," ISRN Chromatography, vol. 2012, Article ID 278583, 7 pages, 2012.

[5] P. P. Vekariya and H. S. Joshi, "Development and validation of RP-HPLC method for azilsartan medoxomil potassium quantitation in human plasma by solid phase extraction procedure," ISRN Spectroscopy, vol. 2013, Article ID 572170, 6 pages, 2013.

[6] S. Singh, B. Singh, R. Bahuguna, L. Wadhwa, and R. Saxena, "Stress degradation studies on ezetimibe and development of a validated stability-indicating HPLC assay," Journal of Pharmaceutical and Biomedical Analysis, vol. 41, no. 3, pp. 1037-1040, 2006.

[7] M. Bakshi and S. Singh, "Development of validated stabilityindicating assay methods-critical review," Journal of Pharmaceutical and Biomedical Analysis, vol. 28, no. 6, pp. 1011-1040, 2002.

[8] C. D. Niranjan, S. M. Patil, J. K. Sabaji, and A. N. Chivate, "Development of UV spectrophotometric method for estimation and validation of telmisartan as a pure API," Journal of Pharmacy Research, vol. 5, no. 6, pp. 3331-3333, 2012.

[9] K. K. Pradhan, U. S. Mishra, A. Sahoo, K. C. Sahu, D. Mishra, and R. Dash, "Method development and validation of Telmisartan in bulk and pharmaceutical dosage forms by UV Spectrophotometric method," International Journal of Research in Pharmaceutical Sciences, vol. 2, no. 4, pp. 526-530, 2011.

[10] G. Mahathi, Y. Ravindra Reddy, and P. Uttam Prasad, "Development and validation of telmisartan and atorvastatin calcium in combined dosage form by RP-HPLC, International Journal of Pharmacy and Technology, vol. 3, no. 3, pp. 3370-3389, 2011.

[11] A. M. Raja, N. Spoorthy, D. Banji, K. N. V. Rao, C. Vanita, and S. D. Kumar, "Simultaneous estimaton of metroprolol succinate and telmisartan in tablet dosage form by RP-HPLC," Journal of Pharmacy Research, vol. 5, no. 8, pp. 4585-4587, 2012.

[12] P. Vani and S. K. Kalyana, "A rapid stability-indicating simultaneous determenation of hydrochlorothiazide, ramipril and telmisartan in combined dosage form by ultra performance liquid chromatography," Pharmacia Letter, vol. 5, no. 3, pp. 8189, 2013.

[13] K. E. Parmar, R. S. Mehta, N. D. Patel, and K. E. Parmar, "Development and validation of HPTLC method for simultaneous determination of telmisartan and chlorthalidone in bulk and pharmaceutical dosage form," International Journal of Pharmacy and Pharmaceutical Sciences, vol. 5, no. 2, pp. 420425, 2013.
[14] H. S. Karmalkar, V. V. Vaidya, N. A. Gomes, M. P. Choukekar, and M. B. Kekare, "Determination of cilnidipine from pharmaceutical formulation by high performance thin layer chromatographic method," Analytical Chemistry, vol. 7, no. 8, pp. 573-576, 2008.

[15] K.-R. Lee, Y.-J. Chae, J.-H. Lee et al., "Quantification of cilnidipine in human plasma by liquid chromatography-mass spectrometry," Journal of Liquid Chromatography and Related Technologies, vol. 35, no. 2, pp. 308-320, 2012.

[16] P. P. Chaudhari and A. V. Bhalerao, "Method validation for spectrophotometric estimation of cilnidipine," International Journal of Pharmacy and Pharmaceutical Sciences, vol. 4, no. 5, pp. 96-98, 2012.

[17] P. Pawar, S. V. Gandhi, P. B. Deshpande, B. Padmanabh, S. Vanjari, and S. U. Shelar, "Simultaneous RP-HPLC estimation of cilnidipine and telmisartan in combined table dosage form," Chemica Sinica, vol. 4, no. 2, pp. 6-10, 2013.

[18] P. Pawar, P. B. Deshpande, S. Gandhi, and V. Bhavnani, "High performance hin layer chromatographic determenation of cilnidipine and telmisartan in combined dosage form," International Research Journal of Pharmacy, vol. 3, no. 6, pp. 219-222, 2012.

[19] G. J. Kher, V. R. Ram, K. L. Dubal, A. H. Bapodara, and H. S. Joshi, "Validation of a stability-indicating LC method for assay of leflunomide in tablets and for determination of content uniformity," International Journal of ChemTech Research, vol. 3, no. 2, pp. 523-530, 2011. 

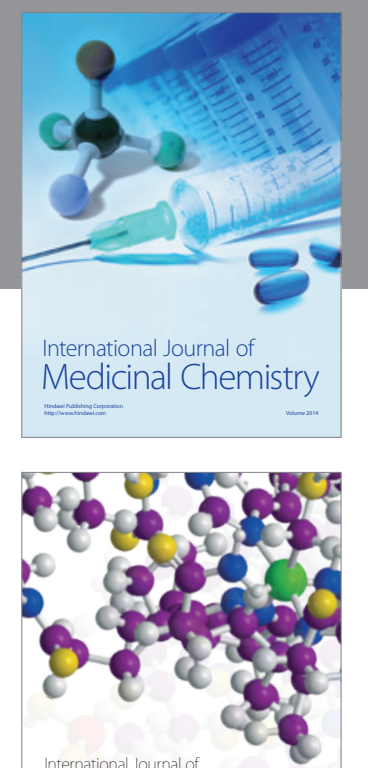

\section{Carbohydrate} Chemistry

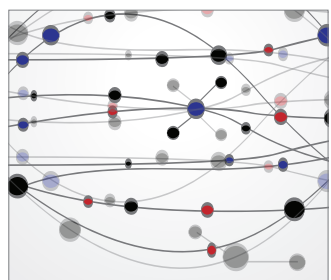

The Scientific World Journal
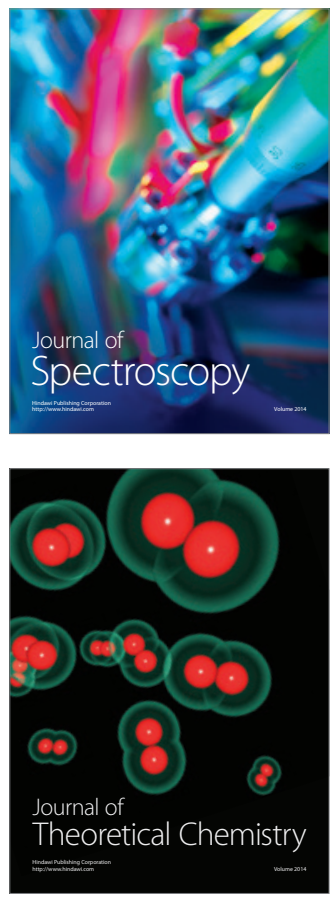
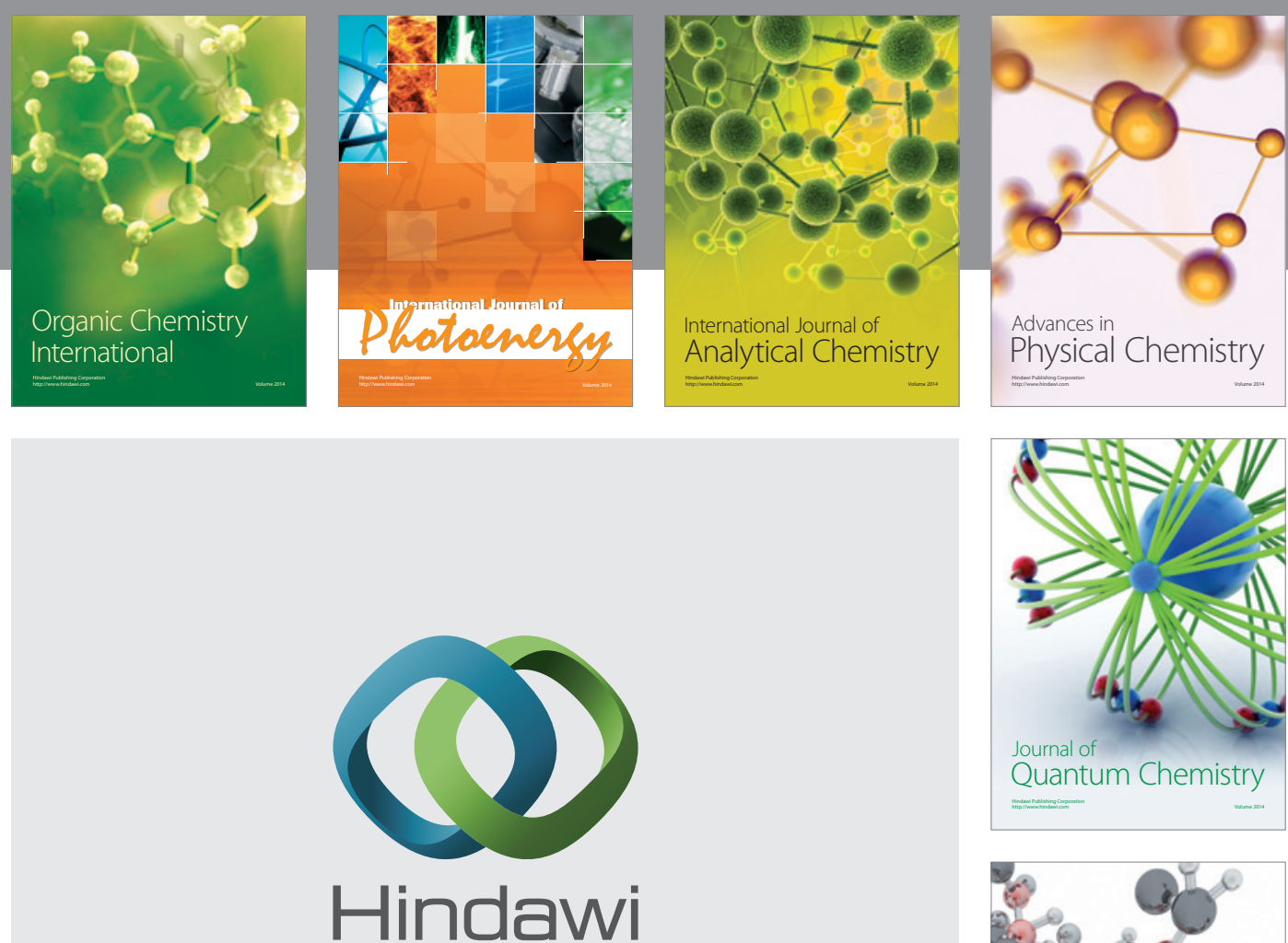

Submit your manuscripts at

http://www.hindawi.com

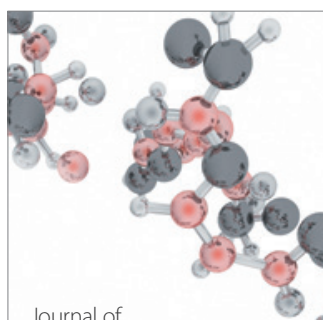

Analytical Methods

in Chemistry

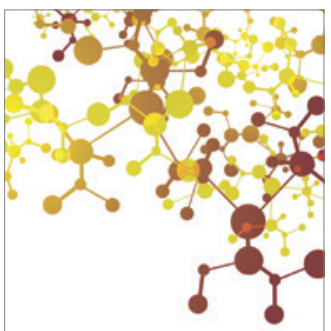

Journal of

Applied Chemistry

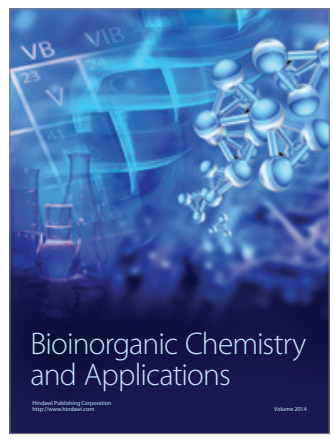

Inorganic Chemistry
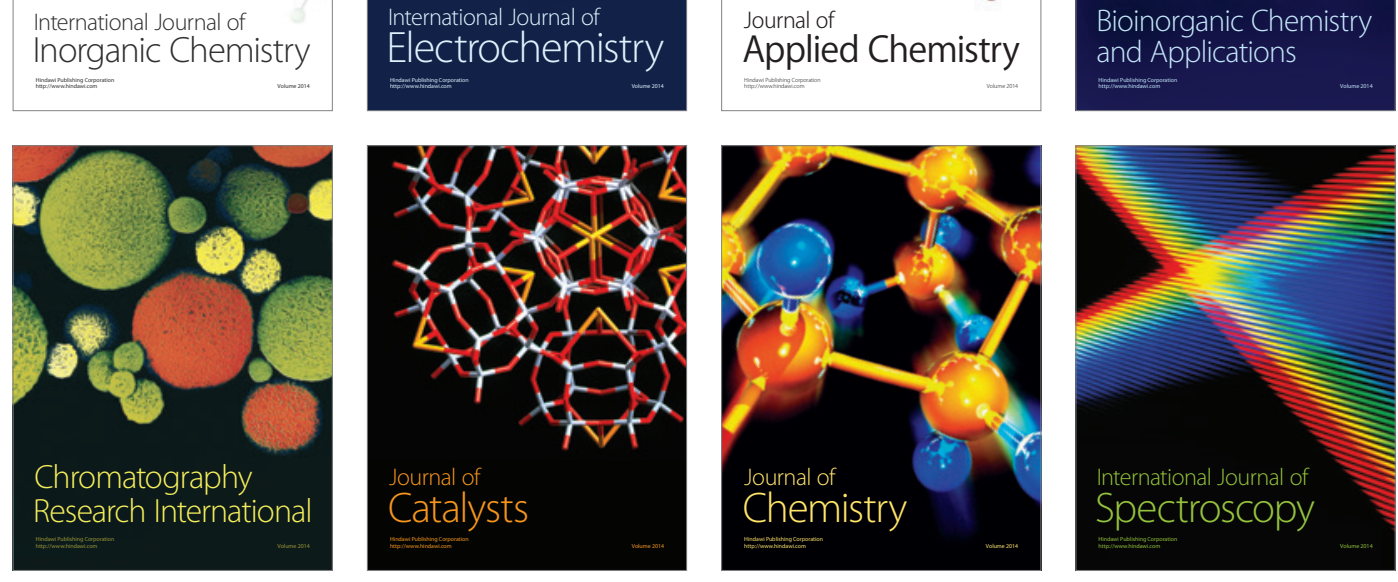